\title{
Political Theology of Zimbabwe's Land Reform: Churches at Cross roads in Zimbabwe from 1890-2017
}

\author{
Goronga Paul $^{1}$ and Dimingu Caroline ${ }^{2}$ \\ ${ }^{1}$ Lecturer in the department of Theology and Religious Studies, Zimbabwe Ezekiel Guti University, Box \\ 350, Bindura, Zimbabwe. Email Address: goropaul@gmail.com \\ ${ }^{2}$ Lecturer in the department of Theology and Religious Studies, Zimbabwe Ezekiel Guti University, Box \\ 350, Bindura, Zimbabwe. Email Address: carolinedimingu@ yahoo.com
}

\begin{abstract}
The issue of land distribution in Zimbabwe remains complex before and after independence. The socioeconomic imbalances can be traced from the pre-colonial era up to date. The paper seeks to show that the Zimbabwe Catholic Bishops Conference (ZCBS), Zimbabwe Council of Churches (ZCC) and civil society are integral in bringing political transformation and assist in solving some of the constitutional challenges Zimbabwe is facing today. The objectives of the paper are to address the socio-economic imbalances which have bedevilled the country and proffer effective mechanisms to manage these conflicts. The study used a descriptive survey approach. The research instruments used are interviews and unstructured questionnaires. Simple random sampling was used from fifteen leaders of both the Zimbabwe Catholic Bishops Conference and Zimbabwe Council of Churches in Harare. Ethical considerations have been made. The limitations are that some people may not be prepared to open for fear of victimisation from their respective institutions. The findings are that accountability need to be taken seriously. The recommendations are that churches need to take a prophetic role in addressing land imbalances.
\end{abstract}

Key Words: Accountability, Transformation, Good governance, democracy.

\subsection{Introduction}

Zimbabwe used to be the bread basket of Southern Africa. It had been one of Africa's brightest hopes and it became a model of reconciliation, food security and economic growth. The farm seizure programme plunged the country into economic chaos and poverty. Religious rhetoric has been used by states like Uganda, Kenya, South Africa when other countries were liberalising air waves, Zimbabwe moved to control the dissemination of information (Chitando 2005:55). The paper reviews the history of colonisation, response of Christian alliances before and after independence in Zimbabwe. Theological insights herein, are critical particularly from the findings of the discussion.

\subsection{Statement of the Problem}

Zimbabwe used to be the bread basket of Southern Africa. It had been one of Africa's brightest hopes and it became a model of reconciliation, food security and economic growth. People from neighbouring countries like Malawi, Zambia and Mozambique used to come in search of employment. The farm seizure programme plunged the country into economic chaos and poverty. The unemployment rate is estimated to be $97 \%$ and most people have resorted to informal sector to make ends meet. Churches have been forced to be docile and remain quiet instead of taking a prophetic stance. 
After the signing of the Rudd Concession (1882) between King Lobengula of the Ndebele state and Cecil Rhodes a group of armed settlers, known as the Pioneer Column, in Mashonaland and the subsequent raising of the British flag (the Union Jack) at Fort Salisbury (now Harare) on 12 September 1890 marked the end of indigenous African independence, for ninety years the indigenous people experienced the brutal and violent history of colonialism. In 1891 an order in council declared Matabeleland and Mashonaland British protectorates. The concession permitted British mining and colonisation of Matabele lands between Limpopo and Zambezi rivers, and prohibited all Boer settlement in the region (Todd 2007:20). Rhodes was an atheist, but he understood the uses of organised religion, and by numerous land grants and other incentives he tied the missionaries of many churches and societies to his cape to vision.

In the 1890s missionaries flooded Zimbabwe and lined up to ask Rhodes for huge tracks of land on which to build mission stations. They expected a major turning to Christ for instance the Roman Catholics returned in the wake of the occupation of Mashonaland by the British South African Company forces in 1890 (Todd 2007:20). Infact father Hartmann became chaplain to the "Pioneer Column" advancing on Mashonaland. In 1892 the Jesuits established a mission station at Chiwasha near Harare. In 1898 five missionaries from the Pennsylvania based Brethren in Christ.

Christ Church (BICC) obtained 3, 000 acres in the Matopo Hills for their Matopo Mission because Rhodes said, "Missionaries are better than policemen and cheaper". A series of land grabbing legislation followed. The Native Reserves Order in council in 1898 dispersed the indigenous people onto low - potential arable lands, the communal areas of today (Todd 2007:20). Wesleyan Methodists opened four stations by 1914. The American Methodist Episcopal Church, now United Methodist Church, under Bishop Hartzell's leadership founded its first mission station at Old Mutare in 1898. The United Methodist Church received 13,000 acres at Old Mutare "free and clear" for their "great central mission" in 1898. The Berlin Missionary Society entered Zimbabwe in 1892 and built mission stations at Gutu, Zimuto and Chivi which were all taken over by the South African Dutch Reformed Church in 1907 when the Berlin Society experienced financial difficulties (Matikiti 2012:96). He further argues that the pioneer of Dutch Reformed missions in Zimbabwe was Andrew A. Louw, who founded Morgenster Mission in 1894 next to the Great Zimbabwe Ruins. In 1894 Cecil Rhodes "granted missionaries of the Seventh Day Adventist church a farm of 12, 000 acres at Solusi. Bishop Knight Bruce founded St Augustine's Anglican mission near Penhalonga in 1891. The salvation Army entered Zimbabwe in 1891 and received a farm of 3,000 acres in the Mazowe River Valley. After 1898, several missionary groups entered Zimbabwe. The primary concern of the missionary church was to convert Africans to Christianity. Thus, they established mission farms, which offered social facilities in education and healthy. These served to promote evangelism. When the settler regime of Rhodes started its programme of dispossession, some of the land taken from the Africans was given freely to the missionaries (Bakare 1993:74)

Early Christians were prominent successful farmers (Bourdillon 1982:7). In the Wedza and Makoni districts, many early Christians in the 1920s and 1930s became prosperous using plough and other technological improvements (Ranger 1985:3). Apparently, Christianity can help in the sustenance of cooperative communities, to the economic advantage of all members at the expense of their individual freedom. Theisen (1977:162) holds that religious influence was important in agricultural development and family security, but that these influences could not be related to other variables on a simple linen scale. However, the success of Christians in agriculture cannot be explained simply by reference to the material advisory resources made available by missionary churches. The most successful churches in agriculture are often the small denominations: The Salvation Army, the Brethren in Christ Church, the African Reformed Church and various Independent churches (Daneel 1971:64). By 1914, White settlers 3\% of the population controlled $75 \%$ of economically productive land, and the Africans were confined $23 \%$ of the land (Todd 2007:21). The Land Acquisition Bill, which sought to empower the government to acquire land, was challenged by the director of the Roman Catholic Commission for Justice and Peace in an article which appeared in the Herald of February 28, 1992. He says:

\footnotetext{
"The legislation is a bad one because it gives one man, the Minister, unwarranted and extraordinary powers. It denies (farmers), protection of the law. It has the potential to encourage corrupt practices. It will seriously threaten both the agricultural sector and the agricultural finance sector. It will not solve, but worsen, the position of the country's food security. For these
} 
reasons, we earnestly request the Executive to reconsider this legislation, and to engage in further consultation so that a scheme for resettlement can be devised which will have real long-term benefits for the whole country." (Todd 2007: 21)

It is interesting to note that the Catholic Commission for Justice and Peace had been a champion on various issues of peace and justice in Zimbabwe, but not on the unjust land tenure acts. The landless who have lived for generations from 1890-1980 do not understand what he means by "serious financial threats if the present agricultural sector is restructured". Todd argues that the director of the Commission for Justice and Peace should have requested all churches who own huge tracts of land given to them by Rhodes "to give it back to the poor and follow Jesus (Todd 2007: 21). The fact that the church owns so much land amidst a landless majority is embarrassing enough. The land apportionment Act in 1930 forced Africans into the labour market. When the Africans were fighting for equal rights in the 1950s the churches were socializing with the government. According to Thomas (1985:113) only when the Africans consciousness developed to the level of demanding political power did the churches begin to demand what the Africans had demanded a decade before. During the 1920s Rev Cripps along with his British allies of Aborigines Protection Society, argued that the land in Southern Rhodesia belonged neither to the British Crown but to the British South Africa Company (BSAC) that had ruled since 1890, nor to the British Crown, but to the African people as the original occupants. Thomas acknowledges two men, Cripps and John White who led a spirited defence of African interests. When Ian Smith came to power, church leaders formed the Christian Council of Rhodesia (CCR) with Bishop Ralph Dodge of the United Methodist Church as its first president. The new council immediately was put to test as the government issued deportation orders in July 1964 to President Dodge. He had been outspoken in opposition both to the proposed Unilateral Declaration of Independence from Great Britain and to the Smith government's practice of detaining persons without trial. Surprisingly, fifty six clergy of various denominations joined with hundreds of United Methodists in public protests (Thomas 1985:114). For the first time, church leaders took to the streets to demonstrate. One month later, Ian Smith banned both African nationalist parties, the Zimbabwe African People's Union (ZAPU) and the Zimbabwe African National Union (ZANU), thereby ending their legal political status in the country. With political leaders in detention and exile, and all secular African newspapers banned, churches had the opportunity to become the voice of the voiceless. It is interesting to note that Roman Catholic leaders and Protestant church leaders worked hand in hand. On 26 November 1965, the CCR voted overwhelmingly to oppose the declaration by Smith. However, the church chose a middle way between tacit approval for the Smith regime and support of guerrilla forces to overthrow it. The Churches at times wavered even before independence. Thus, failing to play a prophetic role. In 1969, the Rhodesia Front introduced constitutional proposals to block forever African progress to majority rule. Catholic bishops met with Protestant leaders of the CCR and agreed on a two - pronged rebuttal. Only the Dutch Reformed clergy criticised this prophetic stand by the churches. Thomas (1985:121) postulates that Rev. Theode Jager, general secretary of the Dutch Reformed Church, charged that the church leaders had exceeded "the bounds of Christ's instruction to the church namely to preach the gospel".

The land Tenure Act, the second pillar of white racialism, evoked a similar concerted protest. By its provision, all land was to be rigidly divided on a racial basis with total ministerial control "to eliminate racial friction arising out of the ownership occupation and use of the land" (Thomas 1985:121). Black and White church leaders feared a loss of freedom to worship together and to live, study and work together at the mission centres. Catholic bishops led the protest and appointed a senior priest Fr. Richard Randolph, to work on land tenure issues. Catholics were the first to promote civil disobedience as an appropriate response to this racist legislative quoting St Peter's cry, "we must obey God rather than men" (Thomas 1985:121). They threatened to close fourteen schools catering to 5000 European children and two major European hospitals. This forced Ian Smith to amend the act and to exempt churches from registration as either a European or an African organisation, or from permits to cross racial lines in working on mission lands.

\subsection{The Coming of American Board of Commissioners for Foreign Missions (ABCFM)}

Matikiti (2012:130) pointed out that in 1893 missionaries of the American Board of commissioners for foreign missions (ABCFM) later named UCCZ, established their first mission stationed at Mount Selinda and the second at Chikore in 1895. Like other missionary societies, the ABCFM was given large areas of land by the British South Africa Company (BSAC) on which to build their mission stations. The ABCFM 
was later named UCCZ in 1981 soon after Zimbabwe attained its independence. The Pioneer missionaries intended to begin opening mission stations from Beira. However, it was found more appropriate to start work at Mt Selinda to ward off the Portuguese expansion into Zimbabwe. Rhodes gave the American Board a farm at Mount Selinda, the mission farm at that time stretched far into present day Mozambique. In 1895 the American Board founded the second major mission at Chikore which is situated $30 \mathrm{~km}$ south of Chipinge. It is on an 18000 acres tract of land that was given to the mission in compensation for land lost at Mount Selinda when the Zimbabwe-Mozambique boarder was defined. The main reason the ABCFM was given land far away from the capital city was the government's suspicion from America were too political and were bound to be revolutionary (Matikiti 2012:130).

The settlers thought that the indigenous people had been defeated after the end of the Ndebele war in 1893. The church was caught up in the middle of the uprising against the white settler who were led by Cecil Rhodes. The Ndebele uprising was crushed in October 1896 and the Shona uprising a year later.

\subsection{Churches' Response Before Independence}

The Roman Catholic and Protestant Churches in Southern Rhodesia supported the spiritual needs of colonialism by providing chaplains for the white column that defeated the Ndebele in 1893. They preached the duty of the representatives of Christian civilisation to overthrow barbarism (Matikiti 2012:130). By possessing land that was taken away from natives, the missionaries demonstrated that they were part and parcel of the colonisation machinery. In Gazaland the natives were relocated to arid and mountainous areas not suitable for human habitation. Apparently, the land issue was one of the major causes of the uprisings. The colonial state itself was a major source of violence. Violence was a major proposition for the institutions that the colonial sate created. In the United Church of Christ's areas of operation, the Boers sometimes used corporal punishment to exact obedience and subservience from those on their farm.

The American missionaries frequently appealed to state authorities and asked for British justice and fair play to be established. Unfortunately, local justice was often meted out before appeals to the far away government could be dealt with Rev Wilder who was a fearless champion of African rights (Matikiti 2012:131). He argued that the Ndau had rights just like Europeans. His self-understanding entailed the church's commitment to defend the weak against the strong in all circumstances. Thus, he was unpopular with white communities and missionaries at the time.

\subsection{Ecumenical Bodies}

Most church denominations were members of the Southern Rhodesia Christian Conference which brought them together at conference to discuss and act on issues affecting their work and the country in general. At these conferences people could pray for justice, peace and God's guidance for the country and its leaders. Institutional injustice permeated all Rhodesian society. ${ }^{28}$ Some church representatives 'walked out' in protest accusing the Christian conference of 'getting involve in politics'. The critical question of whether Christians should participate in armed conflicts has always been a controversial one. It appears that during this period under review the issue of participation was never contested. Largely the feeling of "Kith and Kin" were the motivating factors, which the issue of African rights soundly preferred. (Matikiti 2012:140) Therefore, it was agreed that a separate organisation, which could address itself to the political, social and economic situation in the country be formed. I concur with Matikiti that the formation in 1962 of ecumenical organisation, the Rhodesian Council of Churches, was the result of the need for socio-political relevance of Zimbabwean Protestant Churches.

Matikiti (2012:130) holds that the Churches wanted to find their feet in the impending political and ideological crisis created by the push for the Unilateral Declaration of Independence (UDI) by the white regime in 1962. UDI came into existence in 1965 the Zimbabwe Council of Churches is a major ecumenical body of the Protestant denominations of Zimbabwe, while the Roman Catholic hold only an observer status. The Catholic did not join but rather they formed their own Catholic Commission for Justice and Peace (CCJP) which was the social arm for the church. The following churches were members of the council at its formation: United Church of Christ (American Board), the Anglican Church, the Methodist Church (UK), the Church of Southern Africa, the African Methodist Episcopal Church, the Evangelical Lutheran Church, the London Missionary Society, the Methodist Church Conference (USA), the Independent African Church, 
the Presbyterian Church in Southern Rhodesia, the society of Friends, the Southern Rhodesia Christian Conference, the Salvation Army, the Bible Society the Salisbury Council of Churches, the Christian Marching Church and the young Women's Christian Association. On the other hand, Zimbabwe Catholic Bishops Conference (ZCBC) was made up of Roman Catholic bishops from dioceses in Zimbabwe and catered for specifically Roman Catholic interests. The Heads of Denominations consisted of leaders of both Protestant and Catholic Churches. Bishop Kennedy Skelton of the Anglican Church became the first chairman of the constituting assembly of the new Christian council structure. He was sympathetic to the African cause. Through Bishop Ralph Dodge, the council issued at its constitutional assembly a serious warning to the Prime minister, who was a member of the central Presbyterian Church (Thomas 1985:120). Mr. G. G. Grant of the United Church of Christ (America Board) became the first treasurer of the council.

The churches wanted strength in numbers and to speed with one voice. However, neither the council nor individual denomination responded adequately to the crisis. The council had been handicapped by strong leadership or when it is in chaos itself, then there is a vacuum in the public square with no theological voice on critical issues that touch the lives of the citizens. ${ }^{31}$ There is no one individual accountable with the council since leadership rotates among various denominational leaders. This has led the council to choose middle ground position in ordered to maintain the tradition of the denominations that form it.

The churches entry into politics intensified after the 1969 constitution in extended racism and segregation. The church was averse to injustice. It became prophetic and stood as a pillar of hope and motivation to the majority. Bishop Muzorewa said, "If religion just means to go to church and pray, then it is a scandal. (Thomas 1985:130). The gospel is concerned about where a human being sleeps, what a person earns and how he/she is treated by the government.

The relationship between the church and state became hostile when the World Council of churches resolved to aid liberation movements getting a majority of 23 to 4 votes. The World Council of churches, through its programme to conduct Racism, supported the liberation movement of Zimbabwe. Discrimination culminated in the 1969 Land Tenure Act which while repealing the Land Appointment Act, re-enacted and strengthened its provisions by dividing the land in half with 44, 9 million acres allocated to each race (Thomas 1985:130). The policy was entrenched in a new constitution. These measures led to further overstocking very high population densities serious environmental damage, reduced agricultural productivity and poverty in the communal areas and fragile land, posing great, environmental risks.

It is therefore against this background that land ranked highest among the grievances that motivated the indigenous black majority to launch the second Chimurenga to free the country from colonisation. Churches were profoundly involved in securing the liberation of Zimbabwe. Some notable white bishops like bishops Lamont and Skeleton and brother Arthur Dupuis were deported by the colonial government for supporting blacks.

\subsection{Land Reform Programme After Independence}

In 1980, when independence was won, close to 6000 White commercial farmers owned 15.5 million hectares or $45 \%$ of the most productive land. By 1990, the White community still held $80 \%$ of the land it owned prior to Zimbabwe's independence. Mugabe then introduced Land Acquisition Act allowing the government to acquire land where required. But the government lacked money, especially as the International Monetary Fund (IMF) and the World Bank (WB) were insisting that the land had to be purchased at full market prices (Todd 2007:21). In 1997, Mugabe's government took the only option, to acquire land compulsorily for redistribution. The World Bank acknowledged that large scale of white farmers had utilised less than half of the 11.26 million hectares they own. In 1998 at a conference on land reform in Harare, forty - eight countries and international organisations from the "donor" community unanimously endorsed the need for land reform as being "essential for poverty reduction, economic growth and political stability (Todd 2007:21). In April 2000, Mugabe's government moved further and adopted a constitutional provision authorising the government to acquire land without compensation. The assumption was that compensation would be paid by the United Kingdom. Apparently, Britain refused although she had promised repatriation to evicted white farmers. 
There are three phases of land Reform which characterised Zimbabwe. The first phase was from 1980 to 1996 - Land Reform Resettlement Programme (LRRP 1). The second one dubbed phase 2 was in 1997 to 2000 - The Land Reform Resettlement Programme. Phase 3 was in 2000 to 2002 - Fast Track Land Reform Programme. From the year 2000, the government has encouraged war veterans to seize and occupy white owned commercial farmers. (Moyo 2000:6) These invasions claimed the lives of both white and black citizens, forced thousands off their farms, left close to two million black farm workers and their dependants without their livelihoods and destroyed the agricultural system. Much of the land seized remains unproductive because of lack of expertise, support and inputs. Coupled with drought, Zimbabwe has gone from producing enough food to export to the entire southern African region to being heavily dependent of food aid. This is either continuation of phase 11 or a phase underpinned by a new political debate (Sachikonye 2003:3). The process which displaced the commercial farm workers was chaotic, violent disorderly and researchers have found it difficult to work in an insecure environment (Dombo 2014:34).

\subsection{Christian Alliance and Conflict Resolution and Reconciliation to 2008}

Circumstances as leading to the formation of Christian alliance meant that its relationship with the government was going to uneasy. The Zimbabwe Christian alliance is a joint initiative of various prophetic Christian bodies in Zimbabwe including the EFZ (Evangelical Fellowship of Zimbabwe, Zimbabwe National Pastors Conference (ZNPC), Association of Evangelical in Africa (DEA), Zimbabwe Christian students Movement (ZCSM), Catholic Commission Justice Peace (CCJP), Ecumenical Support Service (ESS), Zimbabwe Orphans

through extended hands (ZOE) Churches in Harare (CIH), Churches in Bulawayo Urban (CIB), Churches in Plumtree (CIP), Churhces in Gweru (CIG), Churches in Victoria Falls (CIV) and Christians together for justce and Peace (CJP). It was formed in 2006 as a direct response to operation Murambatsvina which made several people homeless. As these victims sought shelter in churches, chuch leaders began asking why the children of God were suffering like this. Acoording to Rev Useni "people began to say maybe we need to start to look at the issue of bad governance which is the root cause of this crisis" (Matikiti 2012: 145). We begin to see a new theology among the people.

The mission of the organisation is to bring about social transformation in Zimbabwe through prophetic action. The organisation works to raise domestic and international awareness of issues affecting Zimbabwe. ZCA focuses on decreasing corruption, raising economic equality and justice, creating efficient social services and promoting peace and reconciliation. ${ }^{39}$ Although claiming to be non-violent the fact that the alliance desired to raise both domestic and international awareness to the issue bedevilling Zimbabwe. The formation of ZCA escalated the war of words between the churches in Zimbabwe. In May 2006, the leaders of the ZCC met Mugabe on the eve of the National Day of Prayer and appeared on state television giving support to Mugabe. Christian Council of Rhodesia stood for preservation of justice, civilisation and Christianity against Smith regime, supported guerrilla forces and condemned use of violence and bloodshed. Catholics were first to promote civil disobedience as an appropriate Christian response to racist legislation, quoting St Peter's cry “we must obey God rather men” (Dombo 2014: 20)

\subsection{Response of Church Alliances}

During the 1980s, land reform in Zimbabwe focussed on restitution for past land alienation, promoting equity in land property rights to attain political stability and promoting economic efficiency through reducing the size of land holdings for more efficient use by non - absentee, and socially diverse land owner (Moyo 2000:8). Land reform was defined in the context of promoting national self-sufficiency, focusing upon import substitution, industrialisation and agricultural development strategies led by state interventions in 'land markets'. Land reform was intended to enhance labour intensive small farmer production to optimise land productivity returns to capital invested, the self-provision of food and basic needs, and to encourage less skewed income distribution. This approach promoted positive macro-economic benefits including growth with equity, political reconciliation in a racially polarised society, and more broadly-based participation in the economy (Moyo 2000:8). Zimbabwe faced a multiple of crises: a crisis of legitimacy as its post-colonial consensus crumbles, a crisis of expectations stemming from the failure of its economy and polity and a crisis of confidence in the impartiality of the institutions of the state (Kibble 2004:370) 
However, since the government's defeat in the February 2000 constitutional referendum, ZANU PF has largely succeeded in imposing its control through a 'holistic strategy of repression'. ${ }^{43}$ Zimbabwean churches have not been able to present a united voice in response to the crisis. However, 2003 saw the recovery to the prophetic voice when the leadership of the ZCC publicly apologised to Zimbabwe for not bearing witness to the crisis. This was downplayed by churches seeking to push negotiations and peace building strategy (Kibble 2004:370).

Makaronda observed that when the violence was escalating to unprecedented levels in him, very few voices from the church voiced a position. Traditionally, Christians have looked up to their leaders and to such bodies as the ZCC, EFZ and ZCBC to speak out on behalf of Christians. The Catholic Commission for Justice and Peace (CCJP) conceived reparations in the form of justice, compensation and rehabilitation for the victims of organised violence, to be fundamental to reconciliation (Fisher 2010: 52). Father Oscar Wermter, a Catholic priest, described the political dispensation of the time as dictatorship. He recommended that church leaders in Zimbabwe work in such a way that they would become part of the solution to the nation's problems rather than part of the problem itself. In 2002, Sebastian Bakare, the bishop of the Anglican diocese of Manicaland, admonished Zimbabweans to reject political violence and called for unity and peace among the people of Zimbabwe (Matikiti 2012: 148) Archbishop Pius Ncube conducted a service for peace and justice in Bulawayo. Together with the faithful and St Mary's Catholic Cathedral, Ncube embarked on a peace campaign march on the $6^{\text {th }}$ of June 2002.

At its $37^{\text {th }}$ AGM, the ZCC identified the ongoing socio-economic problems of the country including:

- The people who have starved to death due to food shortage.

- The increasing level of poverty, leaving more and more children on the street.

- The increasing level of poverty, leaving more and more children on the street unemployed.

- Declining productivity due to scarcity of fuel and other commodities.

- The violence, rape, intimidation, harassment and torture ravaging the nation while some perpetrators are set free.

- Political polarisation driving the people.

- Elections then cannot be called free and fair.

- A crumbling health system.

- A land reform programme progressing without proper infrastructure and under cultivated land, resulting in decreased production and went on to say:

\begin{abstract}
"While the church has noted all these developments and while we have continued to pray we have not been moved to action. James says, .....and by my actions I will show you my faith. We as a council apologise to the people of Zimbabwe for not having done enough when the nation has looked to us for guidance. Apparently, the ZCC know that they lack in playing a prophetic role. There is greater need to be courageous and speak against ills being perpetrated in country" (Chitando 2005:220).
\end{abstract}

In an editorial, “ZCC: Are you ready for judgement Day? The Standard bemoaned the church's silence during political violence. The church should be concerned about the whole issue of the struggle for peace, justice and reconciliation in Zimbabwe (Chitando 2005:220). The church had to continue to be the watchdog of democracy and ensure that no impediments were placed in the path of those wishing to exercise their constitutional right to vote. In 2005 ZCC stressed the need for tolerance and respect among citizens and political parties to strengthen democracy and facilitate peaceful political cooperation. In September 2006 ZCBC, the Evangelical fellowship of Zimbabwe and ZCC prepared a discussion document entitled The Zimbabwe We Want: Towards a National Vision for Zimbabwe. In this document the churches implored, interalia, the nation to shun political intolerance (Chitando 2005:220).

The Zimbabwe We Want must cherish, embrace and celebrate a culture of tolerance of dissent, political pluralism and a willingness to accommodate political differences. Intolerance breeds hatred and hatred breeds violence, violence in turn leads to destruction and social rupture. These vices cannot build the Zimbabwe We Want. 
Mugabe pleaded to the WCC in Harare 1998 for the recognition of justice and biblical authority for our claim to repossess the land taken from us in the years of colonialism. Rev Al Simpson, a United Methodist pastor in Chicago and member of Lous Farrichan's nation of Islam delegation that met Mugabe in 2002 encouraged Mugabe to read Joshua 1-18. It is commandment to possess the land, be strong and of good courage. Theological justification of the land redistribution exercise has therefore been an integral part of the ruling party's

Tactics (Chitando 2005:220). He also goes on to argue that the government appealed to Indigenous Religion as fulfilment of the spirit medium Nehanda's prophecy that her bones would rise and defeat whites. However, some chiefs protested use of violence. Therefore, the ruling part claimed legitimacy of religious grounds. In the 1990s a new wave of Pentecostalism swept across Africa. Former deputy minister Tony Gara likened Mugabe to the other Moses as the son of God. ZCBS, EFZ, ZCC issued statements that condemned political violence and called for a culture of tolerance and dialogue. However, ZANU PF remained suspicious. Very few Christian leaders have been able to openly disagree with the appropriation of Christian themes for propaganda purposes in Zimbabwe while Mugabe has been radical in expropriating large-scale commercial farms, he has spared Church land. I concur with Chitando that few black church leaders have been careful not to be too outspoken concerning the land reform. So, the church remains in charge of vast tracts of land (Gundani 2002: 499).

\subsection{Research Methodology}

\subsection{Research Design}

The descriptive method has been used to yield data that can be quantified into frequencies or qualitatively analysed. It is a systematic attempt to collect information to describe and explain beliefs, attitudes, opinions, values and behaviour of groups of people (Babie 1993:55). This method is ideal considering the possible challenges churches are facing on the land question in Zimbabwe rather than other methods such as action research.

Qualitative approach was used since the researcher collected data by interviewing church leaders from different denominations. A semi structure interview guide was constructed to explore the challenges brought by the land reform programme in Zimbabwe. Questionnaires and observation were used as forms of data rather than relying on a single data source (Creswell 2014:185). The researcher also focussed on learning the meaning that the participants hold about the land issue.

\subsection{Population and Sampling}

Tuckman defines research population as the group which the researcher is interested in gaining information and drawing conclusions (Tuckman 1994: 70). It may also refer to the aggregate or totality of individuals from which the sample is chosen (Sidhu 1984:72). As such, the researcher used fifteen church leaders representing ZCC and ZCBS respectively. Two leaders were chosen from the United Methodist Church, two from Anglican Church, two from the Dutch Reformed Church and two from the Salvation Army Church using convenience sampling. On the other hand, seven leaders were chosen from the Catholic Church. Again, respondents were chosen on their convenience and availability. Shumbayaonda (2006: 74) suggests that the sample size for surveys should be more than thirty percent of the total population.

\subsection{Data Collection}

In as far as data collection is concerned the researcher used self-administration to conduct interviews and questionnaires to church leaders in various denominations. Data was then qualitatively processed and summarised into tables and graphs.

\subsection{Limitations and Ethical considerations}

There were financial constraints to visit many areas in Harare and the province of Mashonaland Central Province. Therefore, the research was limited to places close to Harare. Privacy of the participants was considered by the researcher since this is a politically sensitive issue. Pseudo names have been used to avoid any possible victimisation.

\subsection{Discussion of the Findings}


M1 posits that Zimbabwe's political polarisation is reflected among its church leadership. Some within the church are clearly ZANU PF supported having benefited from both the colonial regime and Mugabe's rule. Some received incentives in form of money and farms. The ZCC sees the crisis, to some extent, as issue to be resolved from within the country and African region, not outside it. In 2003 ZCC issued an apology to the people of Zimbabwe for not speaking out or acting against the deteriorating socio-economic condition. Luke 4:18 The

spirit of the Lord is upon me and has sent me to set the captives free. The church should be found to be siding with the poor. M2 argued that although some people feel that different denominations should speak with one voice, it is difficult as various representatives of ZCC do not represent the opinions of their respective churches. M3 argued that both ZCC and ZCBS are not bold enough to speak out on the injustices being inflicted about the disadvantaged people in Zimbabwe, the Catholic Archbishop, Pius Ncube was outspoken against Mugabe in the past few years. The WCC ha made several statements against the worsening law and order situation in Zimbabwe. In 2003 WCC central committee acknowledged the socioeconomic and political crisis in Zimbabwe was a serious challenge to the country's churches and wider ecumenical family. The land resettlement programme has led to serious human rights violations and brought the country to the verge of ruin. It urged member churches to condemn acts of violence in Zimbabwe and expressed support for the Zimbabwe churches' efforts to redress land redistribution inequities. M9 was of the view that WCC is convinced that Zimbabweans can put in place a responsible process of land reform that will do justice to all involved.

However, they will need international bodies and concerned states to assist in Zimbabwe's recovery. M10 was convinced that the fast track land reform was the best approach the government took but was not happy with it was done. She argued that influential people benefitted whilst most ordinary people did not benefit. Some poor people who were lucky to get land they were not given implements. "If there are no inputs it also reduces outputs and it is a pit that 17 years down the line we are still in a crisis, hunger because people were not capacitated", she retorted. The objectives of the government were good, but the challenge is on implementation of the land reform programme. M5 concurred with M4 and added that the land reform programme was Infact a delayed programme. Any leader or President Zimbabwe elected needs to address this issue. However, it is unfortunate that the procedure followed did not have any laid programme to issue land. It could have been done in stages. M6 added that if you know and understand the history of Zimbabwe you would appreciate the fast track reform programme. He added that whites did not bring any cattle or inputs but instead provision of implements came from the colonial government. The same could have been done to newly resettled farmers. Although some few farmers were assisted with basic implements such as seed, people were already impoverished. As a result, they ended up abusing them. When the white settlers came in Zimbabwe they were given adequate time to prepare land for tillage. It took quite some time at times up to seven years before getting settled. It is a process and not event. If the new settlers are given adequate inputs, they will produce the much-desired result.

When queried on the stance of ZCC on the land issue, M7 responded that ZCC and ZCBS were not silent since it comprises different churches. Bishops were sent to confront the President of Zimbabwe to avoid torture and killing during land reform programme. Bishops from different denominations went to Masvingo talking about the 'Zimbabwe We Want'. It is unfortunate that the church leaders dined with the Politicians and even got incentives in form of land and money. This ended up compromising the churches' stand on being objective. Therefore, the ZCC might not be necessarily representing the voices of their respective churches. M8 added that people are also afraid of victimisation. This is unfortunate because the church is supposed to play a prophetic role. M8 also bemoaned leaders who dine with politicians. Although it is difficult to separate religion and politics there is need to be firm with political leaders. It is unfortunate that instead of criticising corrupt leaders, some church leaders go on to accept incentives such as land.

\subsection{Conclusions}

The land issue was imbued with religious significance with the ruling party presenting itself with the ruling party presenting itself with the divine task of empowering blacks. Mugabe's land reform policy appealed to many disadvantaged people in the developing world. Although few people benefited from the land reform 
programme a lot needs to be done to the majority who are still suffering. Churches were supposed to play a leading role in policy formulation towards land reform in Zimbabwe. The Christian alliances really need to play a prophetic role and symphathise with the poor and the vulnerable if they are to be relevant in the country. However, the main challenge is that they are beneficiaries to the colonial regime. Empathy with the disadvantaged would be more ideal for church organisations in the country.

\subsection{Recommendations}

- ZCC needs to take a prophetic stance towards land resettlement in Zimbabwe.

- Church leaders must reach out to the disadvantaged, landless members in the society.

- There is need for interfaith dialogue among different denominations to reach a consensus on the best solution for Zimbabweans.

- Commitment should be reached to speak with one voice.

- There must regular workshops and consultations between church leaders and those in government.

- Churches should hand over idle land to the poor and needy.

\subsection{References}

\section{A Books}

[1] D Tuckman, Conducting Educational Research, (Harcourt and Brace Company, 1994),70-71.

[2] E Creswell, Research Design: Qualitative, Quantintative and Mixed Methods Approaches, (Sage, London, 2014),180-185.

[3] E Babie, The Practice of Social Research, (Wadsworth Publishing House, Belmont, 1983), 54-57.

[4] J L Fisher, "Pioneers, Settlers, Aliens, Exiles. Zimbabwe's discourse of National Reconciliation". (ANU Press, 2010), 52-158.

[5] J R Theisen, The cultivation of Vleism Kwekwe Tribal Trust Land. Tribal Areas of Rhodesia Research Foundation - 1977 Variables of Population Growth. (Harare, (Zambezia,1973),162

[6] K S Sidhu, Methodology of Research in Education, (Sterling Publishers, Jakandlah, 1984),72

[7] L M Daneel, Vapostori veMarange. Social Analysis, No 7. Old and New in Southern Shona Independent Churches Vol 1: Background and the Rise of the Major Movements, (The Hague, Mouton, 1971), 64

[8] S Bakare, My Right to Land - in the Bible and in Zimbabwe. A Theology of Land in Zimbabwe, (Delsinki, Mutare, 1993), 74.

\section{B Articles}

[1] L M Sachikonye "Staying Poor: Chronic Poverty and Development Policy", Land Reform for Poverty Reduction? Social Exclusion and Farm Workers in Zimbabwe, (Harare, FCTZ),2003. p3-4. O T Ranger, "Poverty and Prophetism: Religious Movements in the Makoni District 1924-40. Henderson Seminar No 51, (University of Zimbabwe. History Dept), 1985.

\section{Journals}

[1] A Todd "A Chronicle of Land," The Black Scholar, Vol 37. No 1, The Struggle in Zimbabwe, (2007), 20-22.

[2] CFM Bourdillon, "Christianity and Wealth in Rural Zimbabwe", Journal of Royal Anthropological Institute of Great Britain and Ireland, (1982), 7-9.

[3] E Chitando, (2005) "In the Beginning was Land: The Appropriation of Religious Themes in Political Discourses in Zimbabwe", Africa Journal of the International African Institute, Vol 75, No 2, (2005), 220-229.

[4] E N Thomas, "Church and State in Zimbabwe," Journal of Church and State, Vol 27, No 1, (1985), 113-133.

[5] H P Gundani, "The Land Crisis in Zimbabwe and the role of the Churches towards its resolution", Studia Historiae Ecclesiasticae 28 (2), (2002), 122-129. 
[6] S Dombo, "Refusing to be Co-opted? Church Organisations and Reconciliation in Zimbabwe with special reference to the Christian Alliance of Zimbabwe 2005-2013," Journal for the study of Religion, Vol 27, No 213, (2014), 7-171.

[7] S Kibble, "Zimbabwe. The Government wants the people to give up hoping, Archbishop Pius Ncube, Bulawayo," Journal Review of African Political Economy, Vol 3, No 100, Two cheers? South African Democracy's First Decade (2004), 364-372.

[8] S Moyo, "The Political Economy of Land Acquisition and Redistribution in Zimbabwe, 1990-1999", Journal of Southern African Studies, Vol 26, No 1 (2000), 5-28.

[9] D Thesis

[10] R Matikiti, "Christian Theological Perspectives on Political Violence in Zimbabwe: The case of the United Church of Christ in Zimbabwe" (PhD Dissertation, University of Zimbabwe, 2012), 96-145.

[11] T W Shumbayaonda, "An Analysis of Factors that Determine Teaching Practice Supervisions Effectiveness in Primary Teachers Colleges" (PhD Dissertation, University of Zimbabwe, (2006), 74-75.

\section{E Internet Sources}

[1] http://www.jstor/stable 2639547 [Accessed 04/09/17] 